\title{
Article \\ One-Step Synthesis of Iron and Titanium-Based Compounds Using Black Mineral Sands and Oxalic Acid under Subcritical Water Conditions
}

\author{
Carla S. Valdivieso-Ramírez ${ }^{1}$, Patricia I. Pontón ${ }^{1}{ }^{[}$, Anja Dosen ${ }^{2}{ }^{(}$, Bojan A. Marinkovic ${ }^{2, *}(\mathbb{C}$ \\ and Victor H. Guerrero ${ }^{1, * \text { (D) }}$ \\ 1 Department of Materials, Escuela Politécnica Nacional, Quito 170525, Ecuador; \\ carla.valdivieso@epn.edu.ec (C.S.V.-R.); patricia.ponton@epn.edu.ec (P.I.P.) \\ 2 Department of Chemical and Materials Engineering, Pontifical Catholic University of Rio de \\ Janeiro (PUC-Rio), Rio de Janeiro 38097, Brazil; adosen@puc-rio.br \\ * Correspondence: bojan@puc-rio.br (B.A.M.); victor.guerrero@epn.edu.ec (V.H.G.)
}

check for

updates

Citation: Valdivieso-Ramírez, C.S.;

Pontón, P.I.; Dosen, A.;

Marinkovic, B.A.; Guerrero, V.H.

One-Step Synthesis of Iron and

Titanium-Based Compounds Using

Black Mineral Sands and Oxalic Acid under Subcritical Water Conditions.

Minerals 2022, 12, 306. https://

doi.org/10.3390/min12030306

Academic Editor: Kenneth N. Han

Received: 11 January 2022

Accepted: 24 February 2022

Published: 28 February 2022

Publisher's Note: MDPI stays neutral with regard to jurisdictional claims in published maps and institutional affiliations.

Copyright: (c) 2022 by the authors. Licensee MDPI, Basel, Switzerland. This article is an open access article distributed under the terms and conditions of the Creative Commons Attribution (CC BY) license (https:// creativecommons.org/licenses/by/ $4.0 /)$.

\begin{abstract}
Black mineral sands are widely used to obtain titanium dioxide, titanium, and, more recently, a variety of iron-titanium oxide nanostructures. Highly corrosive mineral acids or alkalis are commonly employed for this purpose. Hence, it is desirable to find eco-friendly ways to process these minerals, deriving high-added value materials. In this study, an Ecuadorian mineral sand precursor $\left(0.6 \mathrm{FeTiO}_{3} \cdot 0.4 \mathrm{Fe}_{2} \mathrm{O}_{3}\right.$ solid solution) was treated with oxalic acid aqueous solutions under subcritical water conditions. The synthesis was conducted in a batch reactor operating at $155{ }^{\circ} \mathrm{C}, 50 \mathrm{bar}$, and $700 \mathrm{rpm}$ for $12 \mathrm{~h}$, varying the oxalic acid concentration ( $0.1,0.5$ to $1.0 \mathrm{M})$. The as-obtained compounds were physically separated, dried, and analyzed by X-ray powder diffraction, scanning electron microscopy, and Raman spectroscopy. The characterization showed that the precursor was completely converted into two main products, ferrous oxalate, and titanium dioxide polymorphs. Rutile was always found in the as-synthesized products, while anatase only crystallized with high oxalic acid concentrations $(0.5$ and $1.0 \mathrm{M})$. These results open the possibility to develop more sustainable routes to synthesize iron and titanium-based materials with promising applications.
\end{abstract}

Keywords: ferrous oxalate; titanium dioxide; oxalate-based reagent; ferrotitaniferous sands; subcritical water technology

\section{Introduction}

Ilmenite $\left(\mathrm{FeTiO}_{3}\right)$ black mineral sands have been traditionally used worldwide to generate concentrated titania slag or synthetic rutile as feedstock for further production of titanium dioxide $\left(\mathrm{TiO}_{2}\right)$ and titanium metal (Ti) [1-4]. Nevertheless, either the generation of such feedstocks or the downstream processes that lead to the commercialized titaniumbased products involve energy-intensive processes $\left(\mathrm{T}>1200^{\circ} \mathrm{C}\right)[5]$, the use of corrosive mineral acids (i.e., sulfuric, nitric, and hydrochloric acids) as leaching agents, as well as the generation of toxic tails and large volumes of industrial sewage that must be treated before disposal [6,7]. During the last few years, these sands have also been used to synthesize different types of iron-titanium oxide nanostructures, whose promising applications have motivated continuous research around the world [8-10]. The alkaline hydrothermal treatment, for example, is a common route to obtain such nanostructures (i.e., ferrititanate nanosheets, iron-doped titanate nanofibers, ilmenite nanoflowers, iron-titanium oxide flower-like micronic particles, and nanobelts) [8,9,11-13]. However, it involves the usage of strongly alkaline aqueous solutions, commonly with molarities as high as $10 \mathrm{M}$. Although this process is straightforward, it is prone to result in an environmental burden. Recognizing the potentially negative impacts on human health and the natural ecosystems associated with the described processing approaches for ilmenite black sands, it is highly desirable to find sustainable alternatives, through environmentally friendly methods. 
The dissolution of ilmenite black sands is crucial prior to titanium extraction, concentration, and recovery with the ore upgrade. This stage is even more important if we consider that some of these ferrotitaniferous black sands are naturally occurring ilmenitehematite solid solutions (IH SSs), which are more difficult to dissolve, in comparison with the ones composed only of ilmenite [13]. For this reason, efforts have been devoted to the improvement of the throughput of the dissolution stage [14], and to the development of cleaner processing that minimizes the usage of toxic chemicals [4,15]. Organic acids, for example, represent an effective alternative to strong mineral acids in acid leaching. In this regard, oxalic, citric, and ascorbic acids have been demonstrated to be very effective in the dissolution of iron oxides, including goethite, magnetite, and hematite [16-18]. The dissolution of these iron oxides in organic acids has been reported via three processes: (1) adsorption of organic ligands on the particle surface, (2) nonreductive dissolution, which is relevant only at high temperatures, and (3) reductive dissolution, which is the main mechanism and consists of two stages: induction and autocatalysis [19]. Similarly, oxalic and citric acids have been used to dissolve more complex iron-bearing minerals such as pure ilmenite; nonetheless, the phenomena and the precise dissolution mechanisms are not yet well understood [20]. In addition, the chemistry associated with the organic acid dissolution of iron oxides can be further explored as an alternative for the synthesis of high-value products from complex, iron-bearing minerals. As such, ferrous oxalate is a product of iron oxide dissolution, and it can be expected when iron-bearing minerals are also treated with aqueous oxalic acid solutions [20]. On the other hand, organic acids at high temperatures (up to $150{ }^{\circ} \mathrm{C}$ ) have been used to increase the dissolution rate of iron oxides [19] and shorten the reaction times [21], suggesting the potential of hydrothermal technologies for value addition of iron-bearing minerals.

Subcritical water (sCW) technology is an eco-friendly hydrothermal process that uses liquid water within a specific temperature and pressure range $\left(100{ }^{\circ} \mathrm{C}<\mathrm{T}<374{ }^{\circ} \mathrm{C}\right.$; 1 bar $<P<221$ bar) as a reaction medium to induce the dissolution and extraction of various compounds in short reaction times [22]. This is possible due to the modified physicochemical properties of water under subcritical conditions (i.e., increased ionic product and decreased dielectric constant, density, and $\mathrm{pH}$ ), which facilitate solvation of compounds of a wide range of polarities, as well as the transport phenomena in aqueous solutions [23]. Additionally, sCW technology is versatile and can be applied to large-scale production, as the required equipment setup resembles the autoclaves setup used for highpressure metallurgy [24]. Therefore, sCW, as a hot, pressurized, and slightly acidic aqueous reaction medium, can be used as a greener approach to process ilmenite black sands. Additionally, the combination of water with dicarboxylic acids at mild sCW conditions ( $135^{\circ} \mathrm{C}$ and 100 bar) has shown to be a feasible and effective alternative to conventional mineral acid-catalyzed hydrolysis of agroindustrial residues $[25,26]$. Nonetheless, the use of these sCW systems has been limited to biomass conversion [22], and no studies focusing on the simultaneous synthesis of iron and titanium-based compounds from naturally occurring ilmenite black mineral sands have been yet reported in just one step.

Treatment of ilmenite-hematite mineral black sands with aqueous oxalic acid solutions under sCW conditions may allow producing $\mathrm{TiO}_{2}$ and ferrous oxalate $\left(\mathrm{FeC}_{2} \mathrm{O}_{4}\right)$, materials with a wide variety of applications. Titanium dioxide is typically used as an adsorbent and photocatalyst in water and air treatments, a pigment in paints and coatings, an antimicrobial agent or reinforcement in composites, etc. [27-29]. Although ferrous oxalate is less common, it is considered an effective heterogeneous catalyst in advanced oxidation processes for eliminating a series of persistent organic pollutants from wastewaters [30-33]. It can also be a precursor for the synthesis of other materials such as ferrate (VI), whose ion has a strong oxidizing potential, beneficial for water treatment [34]. Furthermore, the thermal decomposition of ferrous oxalate allows for the synthesis of different magnetic nanoparticles, which can be used as adsorbents, catalysts, reinforcements in composites, sensors, etc. $[35,36]$. 
Therefore, the aim of this research was to evaluate the use of the binary oxalic acid $/ \mathrm{H}_{2} \mathrm{O}$ system at $\mathrm{sCW}$ conditions $\left(155^{\circ} \mathrm{C}\right.$ and 50 bar $)$ as an eco-friendly process to obtain, in one step, titanium dioxide and ferrous oxalate from the Ecuadorian ilmenite-hematite solid solution (naturally occurring ilmenite black mineral sands) without the previously mentioned shortcomings associated with mineral acid leaching. The input synthesis variable was the concentration of the oxalic acid solution. The as-synthetized product streams were characterized by X-ray powder diffraction (XRPD), Raman spectroscopy, and scanning electron microscopy (SEM).

\section{Materials and Methods}

\subsection{Materials}

The black mineral sand used in this study was of Ecuadorian origin, with a reported chemical composition of $0.6 \mathrm{FeTiO}_{3} \cdot 0.4 \mathrm{Fe}_{2} \mathrm{O}_{3}$ [37] and milled under the conditions described elsewhere [13]. For the sCW synthesis, oxalic acid (>99.5\%, ACS grade) from Sigma Aldrich (St. Louis, MO, USA), water from the Milli-Q system $(18.2 \mathrm{M} \Omega \cdot \mathrm{cm}$, Millipore, Billerica, MA, USA) and $\mathrm{N}_{2}$ gas (99.9\% purity) from Linde (Quito, Ecuador) were used.

\subsection{Synthesis of Iron and Titanium-Based Compounds under sCW Conditions}

The synthesis was performed in a batch stirred high-pressure reactor system (Berghof BR-500, Eningen unter Achalm, Germany), equipped with a $500 \mathrm{~mL}$ PTFE lined vessel. Ilmenite sand $(0.9 \mathrm{~g})$ and aqueous oxalic acid solutions of determined molarity ( $300 \mathrm{~g})$ were loaded into the reaction vessel and the system was assembled. $\mathrm{N}_{2}$ was used to purge the solution inside the reactor and to pressurize the system up to $18 \mathrm{bar}$. Next, the system was heated up to $155{ }^{\circ} \mathrm{C}$. Once the system reached the set temperature and pressure of 50 bar, the reaction time was accounted for $12 \mathrm{~h}$ under constant stirring of $700 \mathrm{rpm}$. Afterward, the system was cooled down, depressurized and the contents of the reactor vessel collected. The as-synthetized product streams were washed out with Milli-Q water until neutral $\mathrm{pH}$, redispersed in Milli-Q water, and decanted for $2 \mathrm{~h}$. As a result, two fractions were recovered-a whitish suspension containing finer particles (WA) and a yellowish precipitate containing larger particles (WB). Redispersion and decanting were carried out mainly to facilitate the upcoming Le Bail refinement of the as-synthesized products. Finally, these fractions were dried at $37^{\circ} \mathrm{C}$ for $24 \mathrm{~h}$ prior to storage and characterization. The synthesis scheme is depicted in Figure 1, while the sample codification is shown in Table 1.

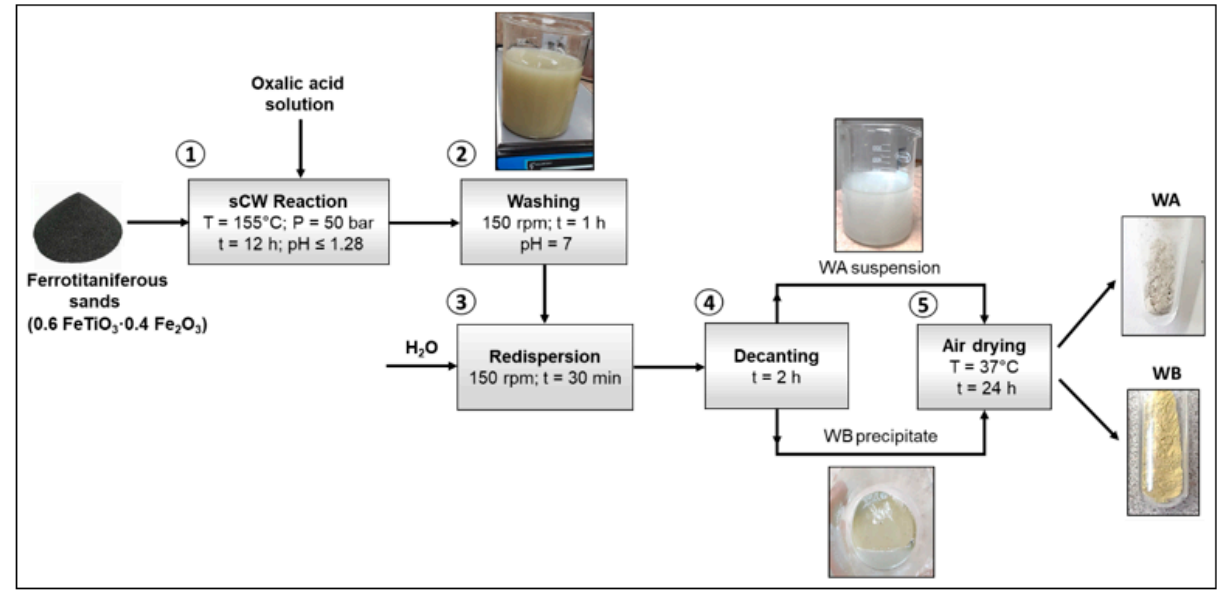

Figure 1. Scheme for the synthesis of iron and titanium-based compounds using a naturally occurring ferrotitaniferous black sand and oxalic acid aqueous solutions at sCW conditions $\left(155^{\circ} \mathrm{C}\right.$ and 50 bar). 
Table 1. Identification of the as-synthesized products.

\begin{tabular}{cccc}
\hline $\begin{array}{c}\text { Oxalic Acid } \\
\text { Concentration (M) }\end{array}$ & Control Sample & $\begin{array}{c}\text { Whitish } \\
\text { Fraction (WA) }\end{array}$ & $\begin{array}{c}\text { Yellowish } \\
\text { Fraction (WB) }\end{array}$ \\
\hline $0\left(\mathrm{H}_{2} \mathrm{O}\right)$ & $\mathrm{sCW}$ & & \\
0.1 & & $0.1 \mathrm{M}-\mathrm{WA}$ & $0.1 \mathrm{M}-\mathrm{WB}$ \\
0.5 & & $0.5 \mathrm{M}-\mathrm{WA}$ & $0.5 \mathrm{M}-\mathrm{WB}$ \\
1.0 & & $1.0 \mathrm{M}-\mathrm{WA}$ & $1.0 \mathrm{M}-\mathrm{WB}$ \\
\hline
\end{tabular}

It is worthy to note that the reaction temperature was selected based on the thermal stability of oxalic acid as the thermal degradation of aqueous oxalic acid solutions has been reported between 160 and $230^{\circ} \mathrm{C}$ [38]. Additionally, relatively low pressure of 50 bar within the sCW region $(1<P<221$ bar $)$ was chosen to keep the aqueous oxalic acid/precursor system at sCW conditions at the operating temperature $\left(155^{\circ} \mathrm{C}\right)$ and to favor the ionization of aqueous oxalic acid and self-ionization of water, as these chemical reactions have been reported to be enhanced by pressure [39-42]. Although short reaction times have been associated with dicarboxylic acid-catalyzed sCW systems, due to the nature of the precursor used in this study, a longer reaction time $(12 \mathrm{~h})$ was defined to ensure that the dissolution and precipitation reactions would occur. A solvent-to-ferrotitaniferous sand ratio of 333:1 was employed, considering the reported ilmenite sand stability in alkaline conditions [13]. In addition, to determine whether the concentration of oxalic acid influences the synthesis reaction, aqueous oxalic acid solutions of $0.1,0.5$, and $1 \mathrm{M}$ were used as solvent media, as well as pure water, which was used as the control solvent.

\subsection{Characterization}

XRPD of the as-synthesized products was carried out in a D8 Advance diffractometer at room temperature ( $\mathrm{CuK} \alpha$ radiation, from 15 to $60^{\circ} 2 \theta$, with $2 \mathrm{~s}$ per $0.02^{\circ}$ step). The phase identification was performed using a PDF-2 database. The CIF files of the identified phases are presented in Supplementary Materials. The acquired diffraction patterns were refined via the Le Bail method, using Topas 4.2 software (Bruker, Karlsruhe, Germany). The morphology and size of the as-prepared products, previously carbon-coated, were studied through SEM analysis, in a Hitachi TM3000 equipment (Hitachi High-Technologies, Tokyo, Japan), operating in secondary electron mode. X-ray energy dispersive microscopy (EDS) mapping was also performed to verify the purity of the as-synthesized powders. These products were also analyzed in a Horiba LabRAM HR evolution Raman spectrometer (Horiba, Kyoto, Japan). The spectra were recorded in the $200-2000 \mathrm{~cm}^{-1}$ region with a grating of $1800 \mathrm{gr} / \mathrm{mm}$ and an acquisition time of $15 \mathrm{~s}$. The spectra collection was at room temperature, using a $633 \mathrm{~nm}$ laser set at $12.5 \mathrm{~mW}$ of power.

\section{Results}

\subsection{Synthesis of Iron and Titanium-Based Compounds under sCW Conditions}

Figure 2 shows the synthesis reaction products (WA and WB) obtained from the ferrotitaniferous mineral sand precursor after $12 \mathrm{~h}$ at $155^{\circ} \mathrm{C}$ and 50 bar using either water or oxalic acid solution of different molarity as reaction medium.

According to Figure 2, it can be inferred that the reaction medium indeed influenced the dissolution of the ferrotitaniferous sand precursor, and subsequently, on the synthesis reaction, as indicated by the color variation in the as-synthesized products. For example, a dark brown powder (Figure 2a) that resembled that of the precursor was obtained with sCW medium whereas yellow, and white powders were obtained with the aqueous oxalic acid medium. In general, ferrous oxalate $\mathrm{FeC}_{2} \mathrm{O}_{4}$ (pale yellow powder) and titanium dioxide $\mathrm{TiO}_{2}$ (white powder) were expected as the primary products formed under the set chemical system with aqueous oxalic acid. Then, the variation in shades of yellow color among the WB fractions (Figure $2 b-d$ ) could be attributed to a possible influence of oxalic acid molarity on the selectivity in reactions. Conversely, Figure 2e shows a sample of the whitish powders (WA fraction) obtained with an aqueous oxalic acid medium, suggesting 
the formation of titanium dioxide. In addition, an average mass ratio of the as-synthesized products WB: WA of 6 was obtained when oxalic acid $/ \mathrm{H}_{2} \mathrm{O}$ was used as the solvent system. However, as expected, there was no formation of fractions WA or WB due to the sCW medium alone.

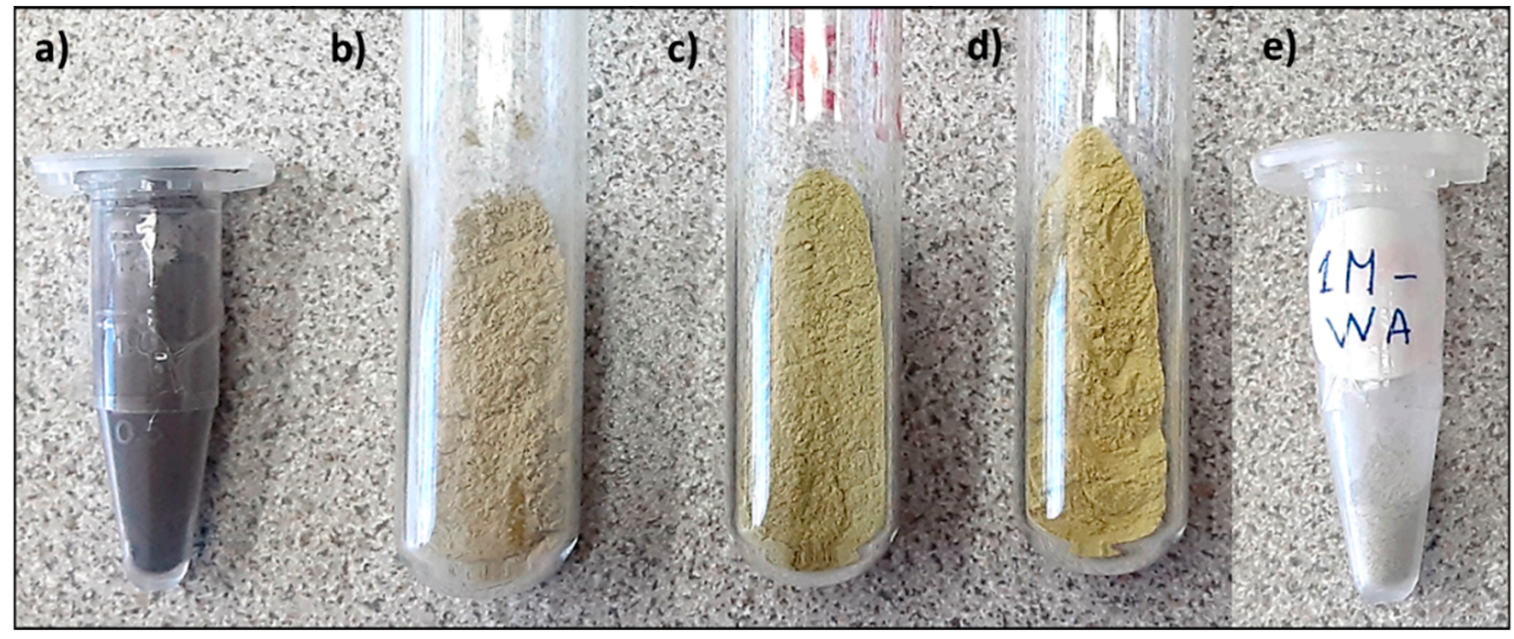

Figure 2. As-synthesized products after the reaction of the precursor sand with oxalic acid solutions at $155^{\circ} \mathrm{C}$ and 50 bar: (a) sCW, (b) $0.1 \mathrm{M}-\mathrm{WB}$, (c) $0.5 \mathrm{M}-\mathrm{WB}$, (d) $1 \mathrm{M}-\mathrm{WB}$, and (e) $1 \mathrm{M}-\mathrm{WA}$ (other WA powders have the same appearance of $1 \mathrm{M}-\mathrm{WA})$.

To gain insights into the effect of the concentration of the oxalic acid solution or water on the dissolution of the precursor, the as-synthetized products were further analyzed by XRPD, SEM, and Raman spectroscopy.

\subsection{Characterization of the Obtained Iron and Titanium-Based Compounds}

Figure 3 shows the XRPD patterns and the SEM images of the ferrotitaniferous sand precursor and the products synthesized with sCW (control medium). The diffraction pattern for the untreated sand precursor exhibited peaks at $2 \theta$ angles that correspond to an IH SS, as previously observed for this type of mineral sand [13,37]. Le Bail adjustment of the diffraction patterns of untreated sand precursor and $\mathrm{sCW}$ treated product indicated a reduction in IH SS unit-cell volume, from $310.4 \AA^{3}$ for untreated sand to $307.6 \AA^{3}$ for sCW product (Figure 3). In accordance with Brown et al., the reduction in unit cells in $\mathrm{IH}$ SS indicates hematite enrichment of IH SS [43]. Considering the appearance of the rutile phase in the diffraction pattern of the sCW-treated sample (Figure 3), it is suggested that ilmenite, Ti-rich, part of the solid solution was partially dissolved during sCW treatment, resulting in the increase in the hematite fraction within IH SS. Therefore, the presence of a weak diffraction line of rutile in the sCW sample, revealed by the Le Bail refinement, can be associated with chemical changes in the ferrotitaniferous sand, possibly due to some partial dissolution of the ilmenite-hematite solid solution under sCW conditions. The Le Bail refinement of the experimental XRPD patterns for the $\mathrm{SCW}$ sample is displayed in Figure S1 (Supplementary Materials). Although at $155^{\circ} \mathrm{C}$ and 50 bar, water produced an acid-like catalytic effect on the ferrotitaniferous sand, further research is needed to better understand the dissolution behavior in $\mathrm{SCW}$.

An SEM image of the untreated ferrotitaniferous sand precursor is presented in Figure $3 b$, revealing that this sample is composed of a mixture of irregular-shaped submicronic particles and micronic particles $(10-40 \mu \mathrm{m})$. After synthesis at sCW conditions, the morphology and shape of the sCW-treated product (control sample) differ from those of the precursor, exhibiting irregular prismatic faceted shapes with various channels on the particle surface, as well as a lower amount of submicronic particles (Figure 3c). The particle size of the sCW sample ranges between 10 and $50 \mu \mathrm{m}$. However, few submicronic particles were also found in this sample (irregular and rod-like shapes). Additionally, no 
trace elements were found in the synthesized products, as demonstrated by EDS mapping (Supplementary Materials; Figures S8 and S9).
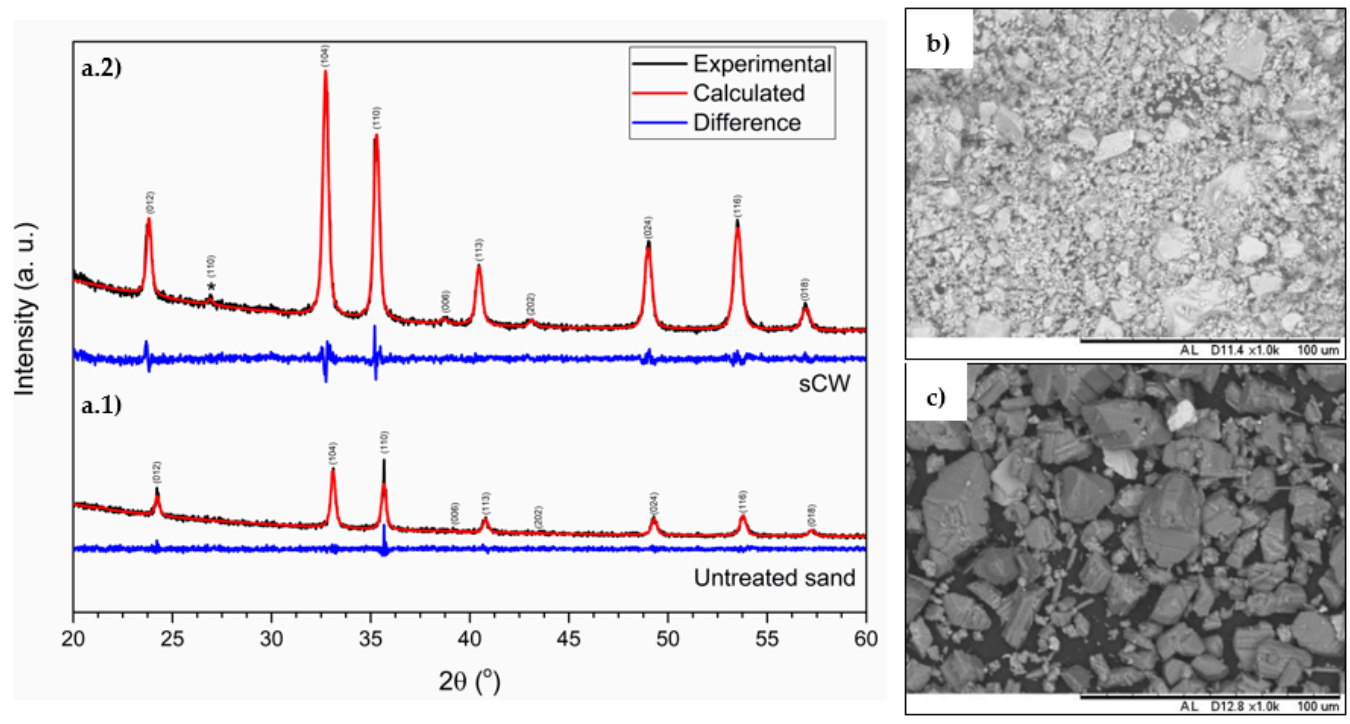

Figure 3. XRPD patterns of the untreated sand precursor (a.1) and the sample treated with sCW at $155^{\circ} \mathrm{C}$ and 50 bar (a.2). Unmarked peaks: ilmenite-hematite solid solution, PDF \#01-070-8143 [13]. Marked peaks: rutile, PDF \#21-1276. Calculated patterns (in red) obtained by Le Bail adjustment. SEM images of (b) untreated sand precursor and (c) the sample treated with sCW at $155{ }^{\circ} \mathrm{C}$ and 50 bar.

Figure 4 indicates the XRPD patterns of the WA fractions obtained using oxalic acid solutions of different molarity at $155^{\circ} \mathrm{C}, 50 \mathrm{bar}$, and $12 \mathrm{~h}$ of reaction. Notably, all the molarities used resulted in the complete dissolution of the black sand. On the other hand, strong peaks of $\mathrm{TiO}_{2}$, in the rutile phase, were identified in all WA samples. Nonetheless, in WA samples obtained with 0.5 and $1.0 \mathrm{M}$ oxalic acid, $\mathrm{TiO}_{2}$ in the anatase form was also present. The unmarked diffraction lines in all WA samples are ascribed to ferrous oxalate hydrate $\left(\mathrm{FeC}_{2} \mathrm{O}_{4} \cdot 2 \mathrm{H}_{2} \mathrm{O}\right)$, matching PDF 23-0293 and PDF 72-1305 (both PDFs correspond to the monoclinic phase but exhibit a different value of $\boldsymbol{a}$ lattice parameter). Overall, WA fractions were rich in $\mathrm{TiO}_{2}$ polymorphs but also contained a significant amount of ferrous oxalate hydrate, suggesting that a sequential redispersion-decanting process can be performed to obtain concentrated $\mathrm{TiO}_{2}$ and $\mathrm{FeC}_{2} \mathrm{O}_{4} \cdot 2 \mathrm{H}_{2} \mathrm{O}$ streams when required. Le Bail refinements of the experimental XRPD patterns of 0.1 M-WA, 0.5 M-WA, and 1.0 M-WA samples, detailing the fitting of each crystalline phase, are shown in Figures S2-S4, respectively (Supplementary Materials).

Figure 5 shows the XRPD patterns of WB products obtained with oxalic acid solutions of different molarity at $155{ }^{\circ} \mathrm{C}, 50 \mathrm{bar}$, and $12 \mathrm{~h}$ of reaction. The main crystalline phase corresponds to ferrous oxalate hydrate $\left(\mathrm{FeC}_{2} \mathrm{O}_{4} \cdot 2 \mathrm{H}_{2} \mathrm{O}\right)$, which is the same compound identified in the WA fractions. Weak diffraction lines of rutile and anatase were recognized, illustrating that the recovered WB fraction almost completely consisted of $\mathrm{FeC}_{2} \mathrm{O}_{4} \cdot 2 \mathrm{H}_{2} \mathrm{O}$. When the oxalic acid concentration was $1.0 \mathrm{M}$, hematite also emerged as a low content secondary phase. Le Bail refinements of $0.1 \mathrm{M}-\mathrm{WB}, 0.5 \mathrm{M}-\mathrm{WB}$, and 1.0 M-WB samples, illustrating the fitting of each crystalline phase, are presented in Figures S5-S7, respectively (Supplementary Materials). Some trace of maghemite was detected in the three WB products, but its diffraction lines are overlapped with those of other phases. 


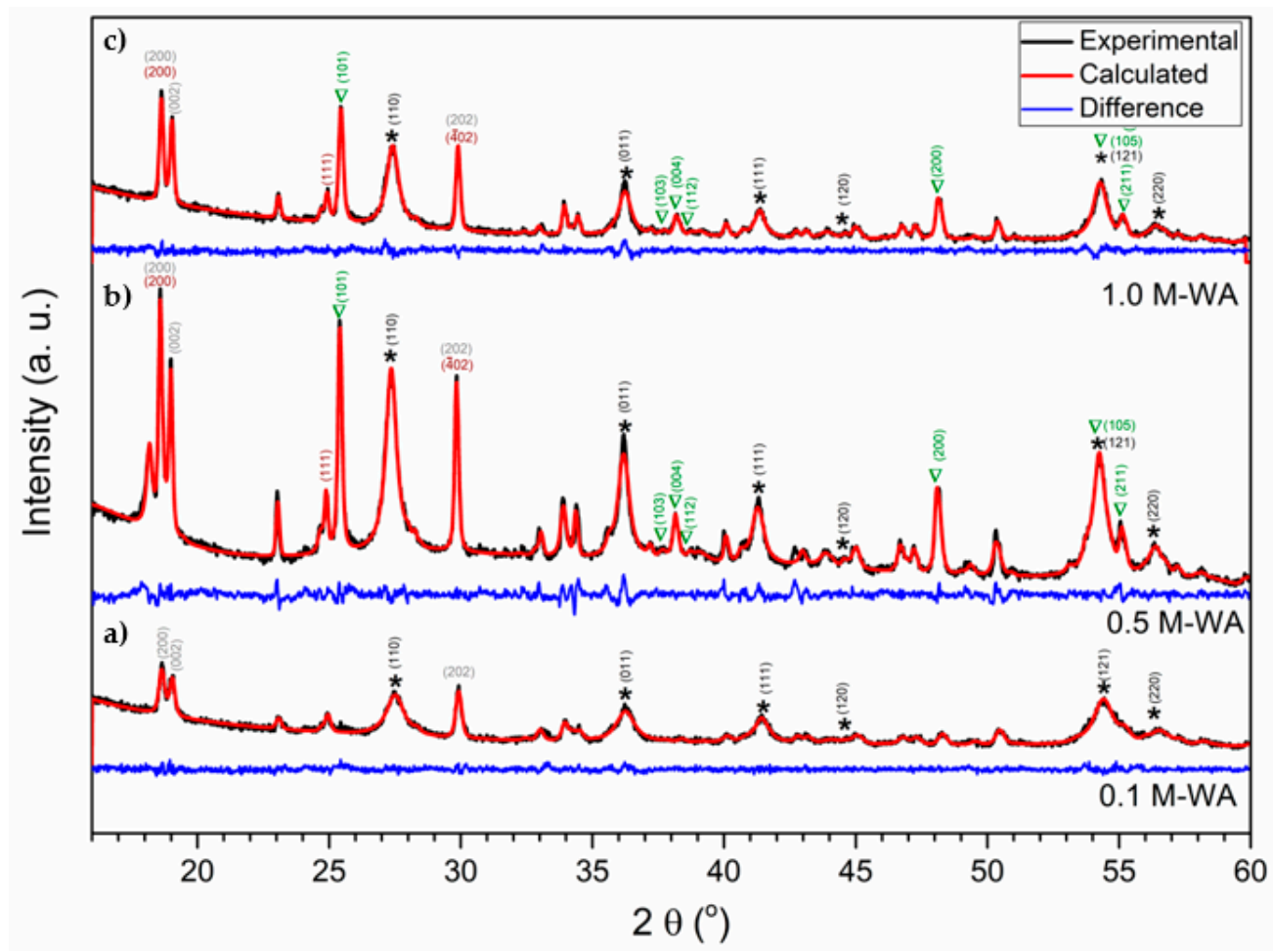

Figure 4. XRPD patterns of (a) 0.1 M-WA powder; (b) 0.5 M-WA powder; and (c) 1.0 M-WA powder, obtained with oxalic acid solutions at $155^{\circ} \mathrm{C}$ and 50 bar. Unmarked peaks: ferrous oxalate hydrated. Main crystalline planes of ferrous oxalate hydrate (PDF 72-1305, a = $12.06 \AA$ ) indexed in brown and those of ferrous oxalate hydrate (PDF 23-0293, a = 9.84 $\AA$ ) in gray. Marked peaks: rutile $\left(^{*}\right)$, PDF \#21-1276 and anatase ( $\nabla)$, PDF \#21-1272. Calculated patterns (in red) were obtained through Le Bail adjustment.

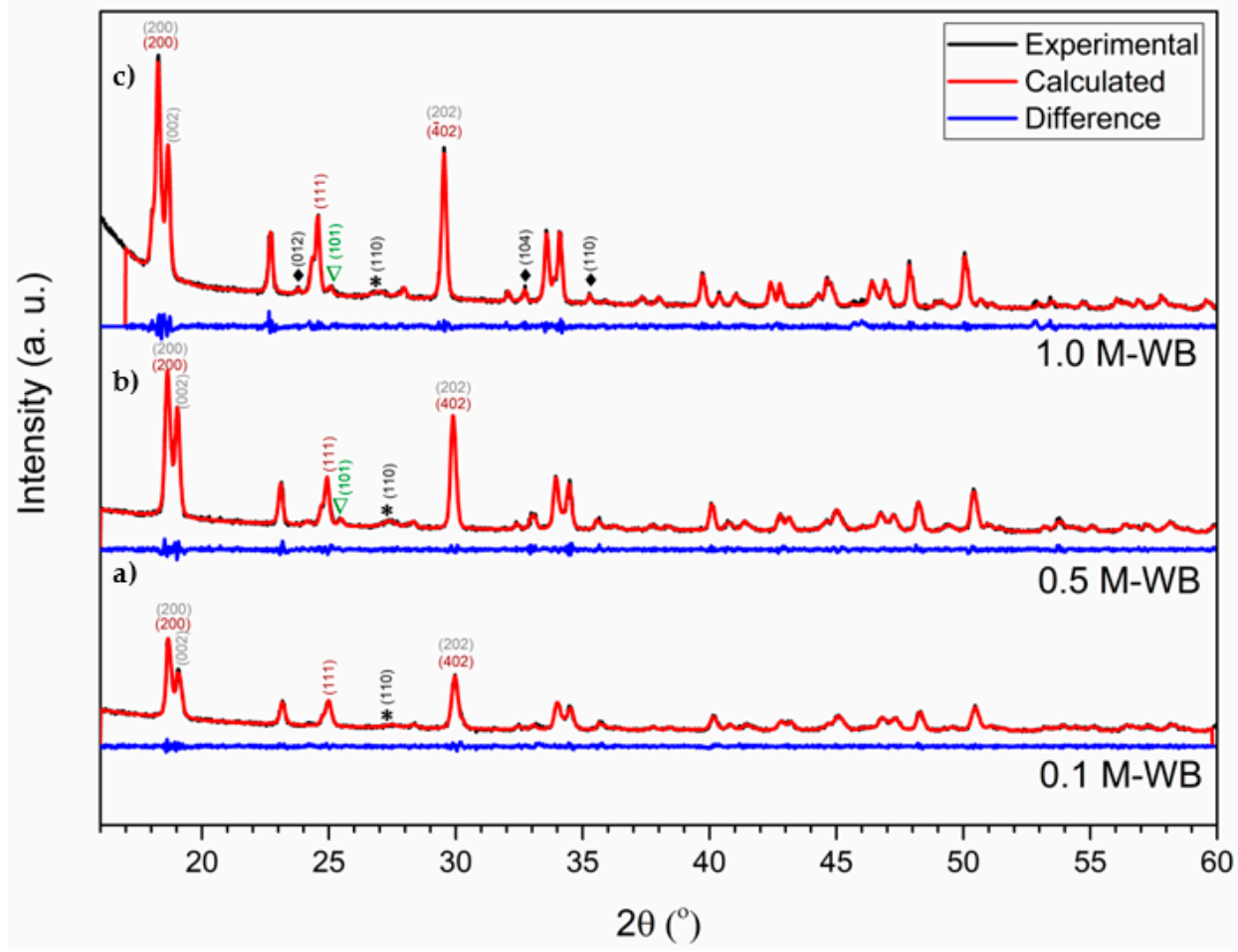

Figure 5. XRPD patterns of (a) 0.1 M-WB powder; (b) 0.5 M-WB powder; and (c) 1.0 M-WB powder, obtained with oxalic acid solutions at $155^{\circ} \mathrm{C}$ and 50 bar. Unmarked peaks: ferrous oxalate hydrate. 
Main crystalline planes of ferrous oxalate hydrate (PDF 72-1305, a = $12.06 \AA$ ) indexed in brown and those of ferrous oxalate hydrate (PDF 23-0293, a = 9.84 $\AA$ ) in gray. Marked peaks: rutile $\left(^{*}\right)$, PDF \#21-1276; anatase ( $\nabla)$, PDF \#21-1272; hematite $(\diamond)$, PDF \# 33-0664. Some weak peaks of trace maghemite overlapped with those of other phases (Supplementary Materials). Calculated patterns (in red) were obtained by Le Bail refinement.

Consistent with the XRPD analyses, the Raman spectroscopic studies of the assynthesized WA and WB products confirmed that titanium dioxide and ferrous oxalate appeared as the main crystalline phases, respectively. Figure 6 shows the Raman spectra of both fractions, WA and WB, obtained using $1 \mathrm{M}$ oxalic acid solution. In Figure $6 \mathrm{a}$, bands corresponding to a mixture of anatase $\left(149,400,516\right.$, and $\left.632 \mathrm{~cm}^{-1}\right)$ and rutile (442 and $614 \mathrm{~cm}^{-1}$ ) were identified [44]. The spectrum presented in Figure $6 \mathrm{~b}$ contains a series of characteristic bands of ferrous oxalate $\left(206,247,521,587,917,1437,1470\right.$, and $\left.1711 \mathrm{~cm}^{-1}\right)$, similar to the ones observed in humboldtine [45] and ferrous oxalate obtained in previous comparable studies [34].
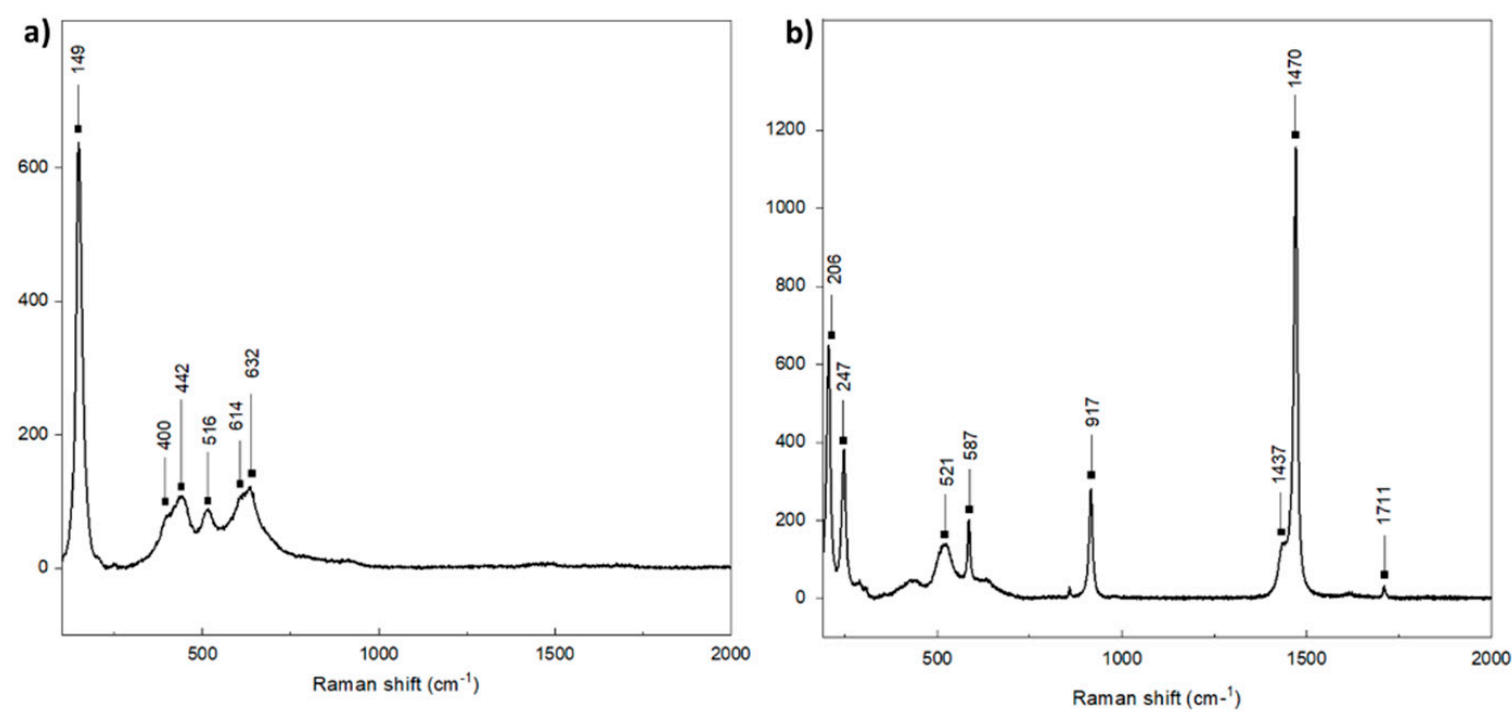

Figure 6. Raman spectra of the (a) 1.0 M-WA and (b) 1.0 M-WB samples obtained using 1.0 M oxalic acid solution at $155^{\circ} \mathrm{C}$ and 50 bar.

Figure 7 displays SEM images of the WA and WB powders. Since all WA fractions (Figure $7 \mathrm{a}, \mathrm{c}, \mathrm{e}$ ) are composed of finer particles (micronic particles $<10 \mu \mathrm{m}$ and submicronic particles), these products remained suspended in the reaction medium, despite containing $\mathrm{TiO}_{2}$ phases, denser than ferrous oxalate. On the other hand, WB fractions (Figure 7b,d,f), rich in ferrous oxalate, comprise larger particles, the majority of them larger than $10 \mu \mathrm{m}$, which decanted. The submicronic particles observed in WB fractions can be related to the $\mathrm{TiO}_{2}$ WA counterparts. As the oxalic acid molarity increases, the quantity of such submicronic particles decreases, as can be seen in Figure 7f. Regarding morphological features, WA powders have irregular-shaped particles, while WB powders exhibit irregular prismatic faceted shapes like slender prisms, similar to those of the sCW sample. 


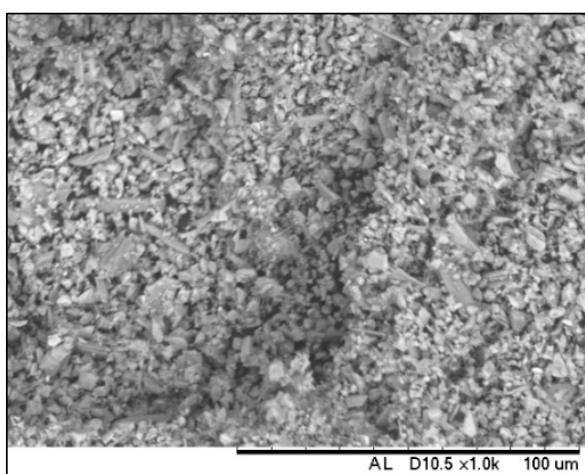

(a)

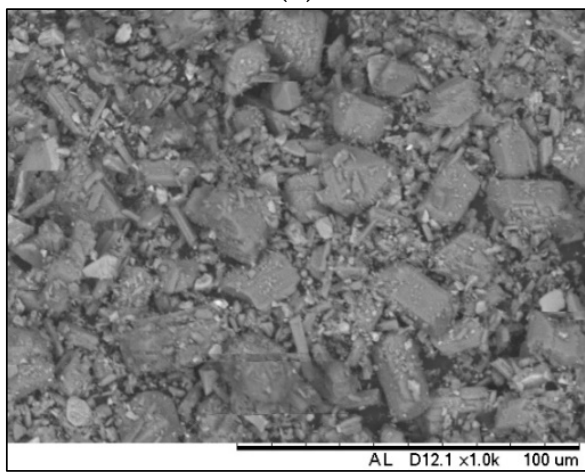

(b)

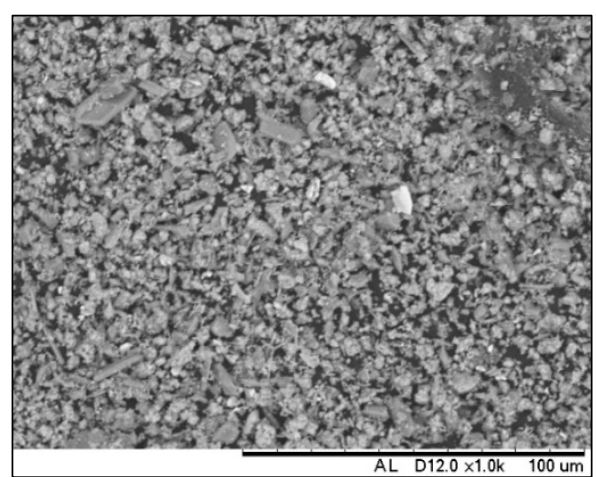

(c)

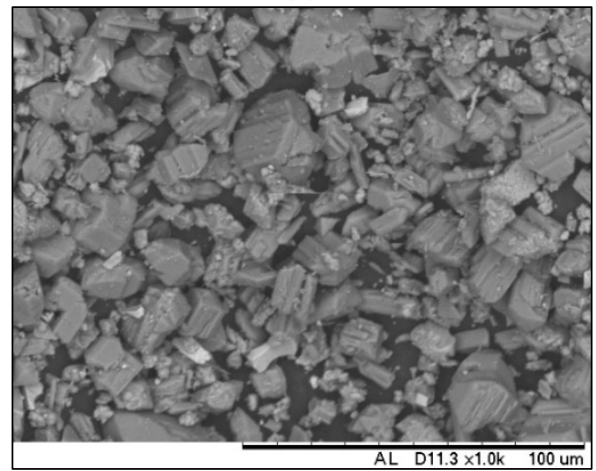

(d)

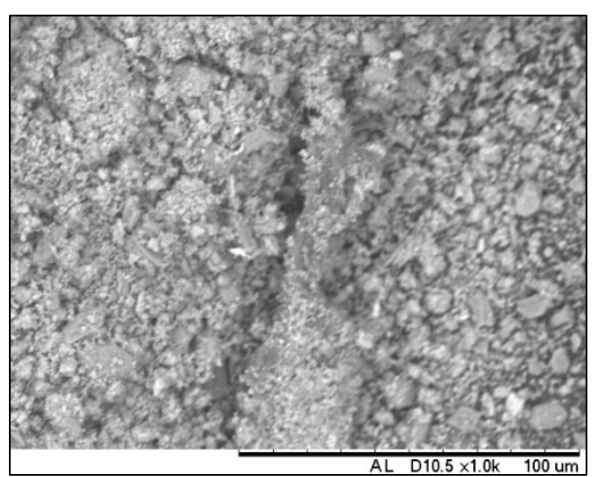

(e)

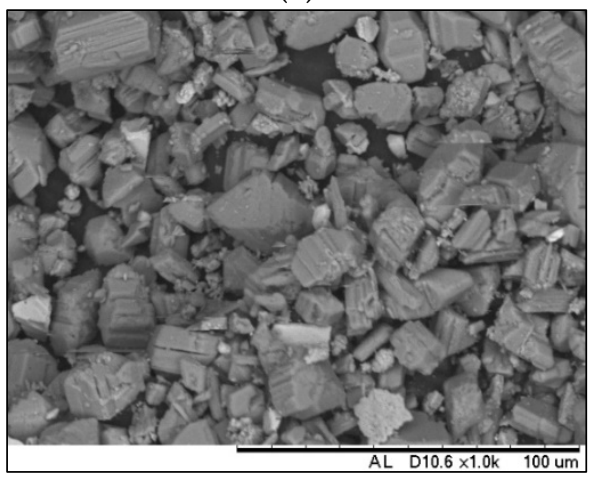

(f)

Figure 7. SEM images of the as-synthetized products: (a) $0.1 \mathrm{M}-\mathrm{WA}$, (b) $0.1 \mathrm{M}-\mathrm{WB}$, (c) $0.5 \mathrm{M}-\mathrm{WA}$, (d) 0.5 M-WB, (e) 1.0 M-WA, and (f) 1.0 M-WB.

\section{Discussion}

Iron and titanium-based compounds were synthesized from ferrotitaniferous mineral sand under sCW conditions (at $155^{\circ} \mathrm{C}$ and 50 bar) using an oxalic acid $/ \mathrm{H}_{2} \mathrm{O}$ solvent system, avoiding the use of conventional high molarity mineral acids and alkaline solutions. The selected solvent system at $155^{\circ} \mathrm{C}$ and 50 bar favored the dissolution of the ferrotitaniferous mineral sand precursor, compared with that of the control sCW medium at $155{ }^{\circ} \mathrm{C}$ and $50 \mathrm{bar}$, and led to the formation of ferrous oxalate and titanium dioxide (rutile and anatase) in just one processing step (Figures 4-6). Although this complex iron-rich ferrotitaniferous sand has been shown to withstand temperatures as high as $180^{\circ} \mathrm{C}$, autogenous pressures, long processing times, and concentrated alkaline solutions [13], in this study, its susceptibility to dissolution in an acidic medium was proven. As such, the dissolution of the precursor can resemble acid catalysis, where the dissolution reactions are driven by proton transfer, followed by a nucleophilic attack so that protic strong acids (i.e., sulfuric, nitric, and hydrochloric acids) act as a source of protons $\left(\mathrm{H}^{+}\right)$to facilitate the catalysis [46]. In the reaction system used herein, the carboxylic groups of oxalic acid (weak diprotic acid) can also act as proton donors in an aqueous medium [47]. Thus, proton transfer and nucleophilic attack mechanisms could be expected during the dissolution of ferrotitaniferous mineral sand precursors. Likewise, $\mathrm{sCW}$ can serve as a protic solvent due to its increased ionic product $\left(\mathrm{Kw}\left(155^{\circ} \mathrm{C}\right)=1 \times 10^{-12}\right.$ vs. $\left.\mathrm{Kw}\left(25^{\circ} \mathrm{C}\right)=1 \times 10^{-14}\right)$ and ionic strength, and consequently reduced $\mathrm{pH}$, facilitating acid-catalyzed reactions [23,48,49]. According to Figure $3 a .2, \mathrm{sCW}$ medium at $155^{\circ} \mathrm{C}$ and 50 bar indeed had a mild acid catalytic effect on the dissolution of the sand precursor as rutile phase was identified by the XRPD analysis, besides IH SS precursor. However, the addition of oxalic acid to reach $0.1 \mathrm{M}$, for example, favored much more the dissolution of the black sand precursor, as the IH SS phase was no longer identified by the XRPD analysis; rather, ferrous oxalate and rutile phases were (Figures $4 \mathrm{a}$ and $5 \mathrm{a}$ ). Based on the abovementioned facts, it can be inferred that the dissolution of the ferrotitaniferous black sand was favored as the proton concentration 
in the reaction medium increased. In addition, Pourbaix diagrams for $\mathrm{Fe}-\mathrm{H}_{2} \mathrm{O}$ [50] and $\mathrm{FeTiO}_{3}-\mathrm{H}_{2} \mathrm{O}$ [15] systems also report that up to $\mathrm{pH} 4$ (high proton concentration), the soluble iron $\mathrm{Fe}^{+2}$ is the predominant species, while titanium still remains as the insoluble oxide $\mathrm{TiO}_{2}$ (s) [15]. To discuss further the influence of oxalic acid concentration on the synthesis reaction, the oxalic acid dissociation constants $\left(\mathrm{Ka}_{1}\right.$ and $\left.\mathrm{Ka}_{2}\right), \mathrm{pH}$, and ionic strength were considered (Table 2). Values in Table 2 corresponding to $\mathrm{pH}$ and ion concentration were calculated based on the concentration of $\mathrm{H}^{+}, \mathrm{C}_{2} \mathrm{HO}_{4}{ }^{-1}$, and $\mathrm{C}_{2} \mathrm{O}_{4}{ }^{-2}$ ions at equilibrium and the acid dissociation constant expressions for oxalic acid (Equations (1) and (2)). The ionic strength of the solution was determined considering the Debye-Hückel equation [51] at equilibrium.

Table 2. Chemical properties of oxalic acid solutions of different molarity and main crystalline phases identified in the as-synthesized product streams obtained with oxalic acid solutions at $155^{\circ} \mathrm{C}$ and 50 bar.

\begin{tabular}{|c|c|c|c|c|c|}
\hline \multirow{2}{*}{$\begin{array}{l}\text { Oxalic Acid } \\
\text { (M) }\end{array}$} & \multirow[t]{2}{*}{$\mathrm{pH}$} & $\begin{array}{c}\mathrm{Ka}_{1} \\
5.6 \times 10^{-2} \\
\end{array}$ & $\begin{array}{c}\mathrm{Ka}_{2} \\
5.4 \times 10^{-5}\end{array}$ & \multirow[t]{2}{*}{$\begin{array}{c}\text { Ionic } \\
\text { Strength (M) }\end{array}$} & \multirow[t]{2}{*}{$\begin{array}{l}\text { Main Crystalline Phases * } \\
\text { (WA + WB) }\end{array}$} \\
\hline & & $\mathrm{C}_{2} \mathrm{HO}_{4}{ }^{-1}(\mathrm{M})$ & $\mathrm{C}_{2} \mathrm{O}_{4}{ }^{-2}(\mathrm{M})$ & & \\
\hline 0.1 & 1.28 & $5.2 \times 10^{-2}$ & $5.39 \times 10^{-5}$ & 0.052 & \multirow{3}{*}{$\begin{array}{c}\text { Ferrous oxalate, rutile } \\
\text { Ferrous oxalate, rutile, anatase } \\
\text { Ferrous oxalate, rutile, } \\
\text { anatase, hematite }\end{array}$} \\
\hline 0.5 & 0.85 & $14.2 \times 10^{-2}$ & $5.41 \times 10^{-5}$ & 0.142 & \\
\hline 1.0 & 0.68 & $21.0 \times 10^{-2}$ & $5.41 \times 10^{-5}$ & 0.210 & \\
\hline
\end{tabular}

${ }^{*}$ Maghemite traces were found in all the reaction products.

As the first dissociation constant of oxalic acid to hydrogen oxalate $\mathrm{C}_{2} \mathrm{HO}_{4}{ }^{-1}$ is significantly higher than that of the second one to oxalate ion $\mathrm{C}_{2} \mathrm{O}_{4}{ }^{-2}$ (Table 2), the $\mathrm{C}_{2} \mathrm{HO}_{4}{ }^{-1}$ is probably the one to play a role in the dissolution reactions. Then, increasing the molarity of the oxalic acid solution will increase the concentration of $\mathrm{C}_{2} \mathrm{HO}_{4}{ }^{-1}$ as well. According to Table 2, for example, as the molarity of oxalic acid solution increases from 0.1 to $1.0 \mathrm{M}$, the concentration of $\mathrm{C}_{2} \mathrm{HO}_{4}{ }^{-1}$ increases 2.7 and 4 times, respectively. Interestingly, such $\mathrm{C}_{2} \mathrm{HO}_{4}{ }^{-1}$ increment was not linear but fitted to a power model regression curve $\left(0.2127 x^{0.6105} ; R^{2}=0.9993\right)$, where $x$ is the molarity of the oxalic acid solution. Therefore, highly concentrated solutions of oxalic acid at the given operating conditions will not dramatically enhance reactions where $\mathrm{C}_{2} \mathrm{HO}_{4}{ }^{-1}$ ion is required. Factors such as temperature, pressure, and time, or its combination, can be further considered to speed up the dissociation of oxalic acid and the generation of $\mathrm{C}_{2} \mathrm{HO}_{4}{ }^{-1}$ ions. In addition, oxalic acid dissociation also generates hydrogen ions $\left(\mathrm{H}^{+}\right)$(Equation (1)), which concentration determines the $\mathrm{pH}$ value. Increasing the molarity of the oxalic acid solution will also increase the concentration of $\mathrm{H}^{+}$but lower the $\mathrm{pH}$ value, as both amounts are inversely proportional. Therefore, the $1.0 \mathrm{M}$ oxalic acid solution exhibits the lowest $\mathrm{pH}$ value of 0.68 , as well as the highest molar ionic strength, which is a measure of the concentration of the electrically charged species in the solution [51], in this case, due to both $\mathrm{H}^{+}$and $\mathrm{C}_{2} \mathrm{HO}_{4}{ }^{-1}$. Consequently, $1.0 \mathrm{M}$ oxalic acid solution as a reaction medium can favor ionic reactions such as acid-catalyzed reactions, compared with those of low molarity. Upon the $\mathrm{sCW}$ synthesis at $155^{\circ} \mathrm{C}$ and 50 bar under a $\mathrm{N}_{2}$ atmosphere, reaction products comprising various mineral phases were obtained when oxalic acid solutions with high molarity and ionic strength were used as reaction media (Figures 4 and 5, Table 2), suggesting that oxalic acid solutions with increased molarity and ionic strength can induce the dissolution of ferrotitaniferous sand as well as the crystallization of other iron and titanium oxides.

Chemical reactions possibly associated with the dissolution of ferrotitaniferous black sand and the synthesis of ferrous oxalate and titanium dioxide at $155^{\circ} \mathrm{C}, 50 \mathrm{bar}$, and $12 \mathrm{~h}$ with aqueous oxalic acid are presented as Equations (1) to (6). According to Equation (1), hydrogen oxalate and hydrogen ions that result from the first ionization stage of oxalic acid are prone to react with the iron-bearing minerals either hematite (Equation (3), [52]) or ilmenite (Equations (5) and (6)), leading to the formation of ferrous oxalate as a precipitate. However, due to differences in chemical composition and valency of iron in the iron-bearing 
minerals, the dissolution rate of either hematite [53] or ilmenite could be favored [54], reducing the amount of the available hydrogen oxalate ion to further react and form more ferrous oxalate (Equation (6)). Then, the rate-limiting step can be associated with the dissociation of oxalic acid. Interestingly, weak acids such as oxalic acid are known for their relatively low dissociation constants, and it is this feature that makes them good candidates for selective catalysis. As such, the oxalic acid medium allows the interaction of the released $\mathrm{TiO}^{+2}$ cation with water to precipitate as titanium dioxide (Equation (5)). Although Equations (1) to (6) provide insights on the expected chemical reactions involved during the synthesis of iron oxalate and titanium dioxide, further studies are needed to confirm the precise mechanistic pathway of the IH SS dissolution in aqueous oxalic acid under pressure and moderate stirring. In addition, the analysis of IH SS by reflected-light microscopy can build up on the understanding of the dissolution of this particular IH SS as segregated hematite lamellae within the ilmenite host, and hematite exsolution segregated at the ilmenite grain borders have been reported in naturally occurring ilmenite ores [55], features that could lead to a specific dissolution mechanism. Conversely, the dissolution mechanism of pure iron oxides, such as hematite, in hot oxalic acid solutions at ambient pressure has been well studied $[53,56]$.

$$
\begin{aligned}
& \mathrm{C}_{2} \mathrm{H}_{2} \mathrm{O}_{4(\mathrm{~s})}+\mathrm{H}_{2} \mathrm{O} \rightarrow \mathrm{H}_{3} \mathrm{O}^{+}+\left(\mathrm{C}_{2} \mathrm{HO}_{4}\right)^{-1} ; \mathrm{K}_{\mathrm{a} 1\left(25^{\circ} \mathrm{C}\right)}=5.6 \times 10^{-2} \\
& \left(\mathrm{C}_{2} \mathrm{HO}_{4}\right)^{-1}+\mathrm{H}_{2} \mathrm{O} \rightarrow \mathrm{H}_{3} \mathrm{O}^{+}+\left(\mathrm{C}_{2} \mathrm{O}_{4}\right)^{-2} ; \mathrm{K}_{\mathrm{a} 2\left(25^{\circ} \mathrm{C}\right)}=5.4 \times 10^{-5} \\
& \mathrm{Fe}_{2} \mathrm{O}_{3}+\mathrm{H}^{+}+5\left(\mathrm{C}_{2} \mathrm{HO}_{4}\right)^{-1} \rightarrow 2 \mathrm{FeC}_{2} \mathrm{O}_{4}(\mathrm{~s})+3 \mathrm{H}_{2} \mathrm{O}+2 \mathrm{CO}_{2} \\
& \mathrm{FeTiO}_{3}+4 \mathrm{H}_{3} \mathrm{O}^{+} \rightarrow \mathrm{TiO}^{+2}+\mathrm{Fe}^{+2}+6 \mathrm{H}_{2} \mathrm{O} \\
& \mathrm{TiO}^{+2}+\mathrm{H}_{2} \mathrm{O} \rightarrow \mathrm{TiO}_{2(\mathrm{~s})}+2 \mathrm{H}^{+} \\
& \mathrm{Fe}^{+2}+\left(\mathrm{C}_{2} \mathrm{HO}_{4}\right)^{-1}+\mathrm{H}^{+} \rightarrow \mathrm{FeC}_{2} \mathrm{O}_{4(\mathrm{~s})}+2 \mathrm{H}^{+}
\end{aligned}
$$

Multistage processes that embrace the utilization of strong mineral acids have been reported for the dissolution of complex iron-bearing minerals such as ilmenite. As such, a mixture of hydrochloric and oxalic acids at $160^{\circ} \mathrm{C}$ for $3 \mathrm{~h}$ has been used to facilitate $\mathrm{TiO}_{2}$ leaching as $\mathrm{TiOCl}_{2}$ by hydrochloric prior to iron dissolution with oxalic acid [57]. Additionally, the use of an oxalic acid ammonium salt to produce titanium dioxide from ilmenite has been patented [58]. Nonetheless, ammonium oxalate, as a leaching agent in ilmenite, leads to a titanium-rich solution (titanium oxalate) that requires further hydrothermal treatment $\left(250\right.$ to $\left.374{ }^{\circ} \mathrm{C}\right)$ or calcination $\left(700-1100{ }^{\circ} \mathrm{C}\right)$ to obtain rutile [58]. Conversely, studies on hydrothermal synthesis $\left(200^{\circ} \mathrm{C}\right.$ and $24 \mathrm{~h}$ ) of different $\mathrm{TiO}_{2}$ polymorphs from pure metallic titanium have revealed that in the presence of oxalic acid, the $\mathrm{pH}(1-10)$ can significantly influence the $\mathrm{TiO}_{2}$ crystalline structure [59]. Thus, anatase formation was reported to prevail at $\mathrm{pH} 2$, while rutile was predominant at $\mathrm{pH} 4$ to 6 [59]. Although the operating sCW conditions $\left(155^{\circ} \mathrm{C}, 50 \mathrm{bar}\right.$, and $12 \mathrm{~h}$ ), the type of precursor, the $\mathrm{pH}$, and oxalic acid concentration used in this study differed from those reported for the hydrothermal treatments, variation in the crystalline structure of the as-synthesized products was also observed due to both $\mathrm{pH}$ difference and oxalic acid concentration.

According to the above-discussed findings, the oxalic acid- $\mathrm{H}_{2} \mathrm{O}$ system at mild sCW conditions (at $155^{\circ} \mathrm{C}$ and 50 bar) exhibited a promising potential as a reaction medium to induce the dissolution of a naturally occurring IH SS black sand but the synthesis of titanium dioxide (rutile and anatase) and ferrous oxalate in a one-step process, without shortcomings associated with the use of conventional toxic leaching agents. In addition, the evaluated synthesis method considers the green chemistry principles, among them waste prevention, atom economy, less hazardous chemical synthesis, safer solvents and auxiliaries, design for degradation, and inherently safer chemistry for accident prevention [60]. Waste prevention, for example, is an advantage of the proposed method since aqueous oxalic acid can be used in low concentrations (i.e., $0.1 \mathrm{M}$ or $0.9 \%, w / w$ ) as a reactant to speed 
up the reaction, and at the end of the reaction time, the remaining nonionized acid can be recycled back and utilized as a solvent for the next synthesis. Additionally, if required, the residual aqueous oxalic acid can be used in other industrial applications [61] such as rust removal [61], chemical pretreatment prior to mechanical pulping [62], as a mordant in dyeing textiles [63], as a chelating agent for heavy metals removal [64-68], etc., allowing to maintain its value as long as possible, which fits also the alignments of a circular economy. It is also worth mentioning that oxalic acid is naturally found in the ecosystem and that oxalic acid cycling by bacterial-fungal interactions has been reported in soils, plants, and animals [69]. Thus, the usage, handling, and potential disposal of aqueous oxalic acid will be a minimal threat to the natural ecosystem.

This study was carried out as proof of concept to investigate whether subcritical water and oxalic acid at $155{ }^{\circ} \mathrm{C}$ and 50 bar could be used as an alternative method for value addition to Ecuadorian black mineral sands. The obtained results showed that, indeed, the evaluated one-step sCW synthesis allows complete transformation of the naturally occurring black mineral sand precursor into products with anticipated photocatalytic effect, preventing further complicated downstream procedures such as hydrolysis, calcination, or addition of crystallization aids. However, more research is needed to better elucidate the dissolution-precipitation reaction mechanisms under $\mathrm{sCW}$ conditions for further optimization of the process.

\section{Conclusions}

Ferrous oxalate and titanium dioxide were synthesized from ferrotitaniferous black sand under sCW conditions at $155^{\circ} \mathrm{C}$ and 50 bar using an oxalic acid- $\mathrm{H}_{2} \mathrm{O}$ solvent system. This selected solvent system favored the dissolution of the black sand precursor, compared with that of the control sCW medium at $155^{\circ} \mathrm{C}$ and 50 bar. The complete conversion of the black sand precursor was achieved even with the lowest concentration of $0.1 \mathrm{M}$ oxalic acid. Interestingly, the rutile phase was identified in all as-synthesized products, probably due to its thermodynamical stability. Anatase phase, however, only started to crystallize when the oxalic acid concentration increased to either 0.5 or $1.0 \mathrm{M}$. In addition, based on the dissociation constant, $\mathrm{pH}$, and ionic strength of the aqueous oxalic acid solutions used in this research, a set of chemical reactions associated with the dissolution of ferrotitaniferous black sand and the synthesis of ferrous oxalate and titanium dioxide at $155^{\circ} \mathrm{C}$ and 50 bar was proposed, in which the rate-limiting step corresponded to the dissociation of oxalic acid. Finally, the relative simplicity and eco-friendly nature of the one-step processing route followed and the wide variety of applications of the as-synthesized products open opportunities for value addition of low-cost natural precursors such as the Ecuadorian black sand used in this study.

Supplementary Materials: The following supporting information can be downloaded at: https:// www.mdpi.com/article/10.3390/min12030306/s1, Figure S1: Le Bail fitting of SCW sample: (a) the main phase is an ilmenite-hematite solid solution and (b) the secondary phase is rutile, Figure S2: Le Bail fitting of WA fraction for $0.1 \mathrm{M}$, demonstrating the presence of (a) rutile and (b) Fe oxalate hydrate (PDF 23-0293, a = 9.84 ̊), Figure S3: Le Bail fitting of WA fraction for $0.5 \mathrm{M}$, showing the presence of (a) rutile, (b) anatase, (c) ferrous oxalate hydrate (PDF 23-0293, a = 9.84 $\AA$ ), and (d) ferrous oxalate hydrate (PDF 72-1305, a = 12.06 ̊), Figure S4: Le Bail fitting of WA fraction for 1.0 M, showing the presence of (a) rutile, (b) anatase, and (c) ferrous oxalate hydrate (PDF 23-0293, a = 9.84 $\AA$ ), Figure S5: Le Bail fitting of WB fraction for $0.1 \mathrm{M}$, showing the presence of main phases: (a) ferrous oxalate hydrate (PDF 23-0293, a = 9.84 $)$ ), (b) ferrous oxalate hydrate (PDF 72-1305, a = $12.06 \AA$ ), and secondary phases: (c) rutile and (d) maghemite, Figure S6: Le Bail fitting of WB fraction for $0.5 \mathrm{M}$, showing the presence of main phases: (a) ferrous oxalate hydrate (PDF 23-0293, a = 9.84 $\AA$ ), (b) ferrous oxalate hydrate (PDF 72-1305, a = $12.06 \AA$ ), and secondary phases: (c) rutile and (d) maghemite, Figure S7: Le Bail fitting of WB fraction for $1.0 \mathrm{M}$, showing the presence of main phases: (a) ferrous oxalate hydrate (PDF 72-1305, a = $12.06 \AA$ ), (b) ferrous oxalate hydrate (PDF 23-0293, a = 9.84 $\AA^{\text {) }}$, and secondary phases: (c) hematite, (d) anatase and (e) maghemite, Figure S8: (a) EDS mapping and 
(b) EDS spectrum of WA fraction for 1.0 M, Figure S9: (a) EDS mapping and (b) EDS spectrum of WA fraction for $1.0 \mathrm{M}$.

Author Contributions: Conceptualization, C.S.V.-R., P.I.P. and V.H.G.; methodology, C.S.V.-R. and A.D.; formal analysis, C.S.V.-R., P.I.P. and A.D.; investigation, characterization, C.S.V.-R., P.I.P., A.D., B.A.M. and V.H.G.; writing-original draft preparation, C.S.V.-R., P.I.P., B.A.M. and V.H.G.; writing-review and editing, C.S.V.-R., P.I.P., B.A.M. and V.H.G.; funding acquisition, P.I.P., B.A.M. and V.H.G. All authors have read and agreed to the published version of the manuscript.

Funding: This research was funded by the Escuela Politécnica Nacional (Quito, Ecuador) Project Grant PIJ-18-01.

Data Availability Statement: The data presented in this study are available in article or supplementary material.

Acknowledgments: The authors are grateful to the Escuela Politécnica Nacional (EPN, Quito, Ecuador), Grant Number PIJ-18-01. The authors also acknowledge the Electroceramics Laboratory (Department of Physics, EPN) for preliminary XRPD analyses. B.A.M. is grateful to CNPq (National Council for Scientific and Technological Development) for a Research Productivity Grant.

Conflicts of Interest: The authors declare no conflict of interest. The funders had no role in the design of this study; in the collection, analyses, or interpretation of data; in the writing of the manuscript, or in the decision to publish the results.

\section{References}

1. Farjana, S.H.; Huda, N.; Mahmud, M.A.P. Life-Cycle environmental impact assessment of mineral industries. IOP Conf. Ser. Mater. Sci. Eng. 2018, 351, 012016. [CrossRef]

2. Filippou, D.; Hudon, G. Minerals, slags, and other feedstock for the production of titanium metal. In Extractive Metallurgy of Titanium: Conventional and Recent Advances in Extraction and Production of Titanium Metal; Fang, Z., Froes, H., Zhang, Y., Eds.; Elsevier Inc.: Amsterdam, The Netherlands, 2020; pp. 19-45. [CrossRef]

3. Venugopal, R.; Sharma, T.; Saxena, V.; Mandre, N. (Eds.) International Seminar on Mineral Processing Technology (MPT-2005); Tata McGraw-Hill Education: New Delhi, India, 2005.

4. Habashi, F. A New Process to Upgrade Ilmenite to Synthetic Rutile. COM 2014, 53rd Annual Conference of Metallurgists, Vancouver, BC, Canada, 28 September-1 October 2014.

5. Gupta, A.K.; Aula, M.; Pihlasalo, J.; Mäkelä, P.; Huttula, M.; Fabritius, T. Preparation of Synthetic Titania Slag Relevant to the Industrial Smelting Process Using an Induction Furnace. Appl. Sci. 2021, 11, 1153. [CrossRef]

6. Zhang, W.; Zhu, Z.; Cheng, C.Y. A literature review of titanium metallurgical processes. Hydrometallurgy 2011, 108, 177-188. [CrossRef]

7. Fang, Z.Z.; Paramore, J.D.; Sun, P.; Chandran, K.S.R.; Zhang, Y.; Xia, Y.; Cao, F.; Koopman, M.; Free, M. Powder metallurgy of titanium-past, present, and future. Int. Mater. Rev. 2018, 63, 407-459. [CrossRef]

8. Jardim, P.M.; Mancic, L.; Marinkovic, B.A.; Milosevic, O.; Rizzo, F. $\mathrm{Na}_{x-y} \mathrm{H}_{\mathrm{y}} \mathrm{Ti}_{2-x} \mathrm{Fe}_{\mathrm{x}} \mathrm{O}_{4} \cdot \mathrm{nH}_{2} \mathrm{O}$ nanosheets with lepidocrocite-like layered structure synthesized by hydrothermal treatment of ilmenite sand. Cent. Eur. J. Chem. 2011, 9, 415-421. [CrossRef]

9. Costa, A.M.L.M.; Marinkovic, B.A.; Suguihiro, N.M.; Smith, D.J.; Costa, M.E.H.M.; Paciornik, S. Materials Characterization Fe-doped nanostructured titanates synthesized in a single step route. Mater. Charact. 2015, 99, 150-159. [CrossRef]

10. Yu, J.; Chen, Y.; Glushenkov, A.M. Titanium Oxide Nanorods Extracted From Ilmenite Sands. Cryst. Growth Des. 2009, 9, 1240-1244. [CrossRef]

11. Simpraditpan, A.; Wirunmongkol, T.; Pavasupree, S. Simple hydrothermal preparation of nanofibers from a natural ilmenite mineral. Ceram. Int. 2013, 39, 2497-2502. [CrossRef]

12. Tao, T.; Glushenkov, A.M.; Liu, H.; Liu, Z.; Dai, X.J.; Chen, H.; Ringer, S.P.; Chen, Y. Ilmenite FeTiO 3 Nanoflowers and Their Pseudocapacitance. J. Phys. Chem. C 2011, 35, 17297-17302. [CrossRef]

13. Lagos, K.J.; Marinkovic, B.A.; Debut, A.; Vizuete, K.; Guerrero, V.H.; Pardo, E.; Pontón, P.I. Towards Iron-Titanium Oxide Nanostructures from Ecuadorian Black Mineral Sands. Minerals 2021, 11, 122. [CrossRef]

14. Gao, F.; Nie, Z.; Yang, D.; Sun, B.; Liu, Y.; Gong, X.; Wang, Z. Environmental impacts analysis of titanium sponge production using Kroll process in China. J. Clean. Prod. 2018, 174, 771-779. [CrossRef]

15. Han, J.; Zhang, J.; Feng, W.; Chen, X.; Zhang, L.; Tu, G. A Clean Process to Prepare High-Quality Acid-Soluble Titanium Slag from Titanium Middling Ore. Minerals 2019, 9, 460. [CrossRef]

16. Blesa, M.A.; Marinovich, H.A.; Baumgartner, E.C.; Maroto, A.J.G. Mechanism of Dissolution of Magnetite by Oxalic Acid-Ferrous Ion Solutions. Inorg. Chem. 1987, 26, 3713-3717. [CrossRef]

17. Cornell, R.M.; Schindler, P.W. Photochemical dissolution of goethite in acid/oxalate solution. Clays Clay Miner. 1987, 35, 347-352. [CrossRef]

18. Deng, B.; Wang, B.; Su, S.; Ding, S.; Sun, W. Recovery of iron from pyrolusite leaching slag by a lab-scale circulation process of oxalic acid leaching and ultraviolet irradiation. Metals 2018, 8, 8. [CrossRef]

19. Panias, D.; Taxiarchou, M.; Paspaliaris, I.; Kontopoulos, A. Mechanisms of dissolution of iron oxides in aqueous oxalic acid solutions. Hydrometallurgy 1996, 42, 257-265. [CrossRef] 
20. Jonglertjunya, W.; Rubcumintara, T. Titanium and iron dissolutions from ilmenite by acid leaching and microbiological oxidation techniques. Asia-Pac. J. Chem. Eng. 2013, 8, 323-330. [CrossRef]

21. Panias, D.; Taxiarchou, M.; Douni, I.; Paspaliaris, I.; Kontopoulos, A. Dissolution of hematite in acidic oxalate solutions: The effect of ferrous ions addition. Hydrometallurgy 1996, 43, 219-230. [CrossRef]

22. Saldaña, M.D.A.; Valdivieso-Ramírez, C.S. Pressurized fluid systems: Phytochemical production from biomass. J. Supercrit. Fluids 2015, 96, 228-244. [CrossRef]

23. Galkin, A.A.; Lunin, V. V Subcritical and supercritical water: A universal medium for chemical reactions. Russ. Chem. Rev. 2005, 74, 21. [CrossRef]

24. High Pressure Acid Leach. Available online: https://www.calderaengineering.com/industries-served/high-pressure-acid-leachand-pressure-oxidation/high-pressure-acid-leach (accessed on 12 February 2022).

25. Valdivieso-Ramírez, C.S.; Sanchez, J.-E.; Ganzle, M.; Temelli, F.; Saldaña, M.D.A. Carboxylic acid-catalysed hydrolysis of polygalacturonic acid in subcritical water media. J. Supercrit. Fluids 2021, 169, 105103. [CrossRef]

26. Valdivieso-Ramirez, C.S.; Temelli, F.; Saldaña, M.D.A. Carboxylic acid-catalysed hydrolysis of rhamnogalacturonan in subcritical water media. J. Supercrit. Fluids 2021, 175, 105268. [CrossRef]

27. Zamora-Ledezma, C.; Negrete-Bolagay, D.; Figueroa, F.; Zamora-Ledezma, E.; Ni, M.; Alexis, F.; Guerrero, V.H. Heavy metal water pollution: A fresh look about hazards, novel and conventional remediation methods. Environ. Technol. Innov. 2021, 22, 101504. [CrossRef]

28. Chen, M.C.; Koh, P.W.; Ponnusamy, V.K.; Lee, S.L. Titanium dioxide and other nanomaterials based antimicrobial additives in functional paints and coatings: Review. Prog. Org. Coatings 2022, 163, 106660. [CrossRef]

29. Almeida, L.A.; Habran, M.; Carvalho, R.D.S.; da Costa, M.E.H.M.; Cremona, M.; Silva, B.C.; Krambrock, K.; Pandoli, O.G.; Morgado, E.; Marinkovic, B.A. The influence of calcination temperature on photocatalytic activity of TiO2-acetylacetone charge transfer complex towards degradation of Nox under visible light. Catalysts 2020, 10, 1463. [CrossRef]

30. Balmer, M.E.; Sulzberger, B. Atrazine degradation in irradiated iron/oxalate systems: Effects of pH and oxalate. Environ. Sci. Technol. 1999, 33, 2418-2424. [CrossRef]

31. Conte, L.O.; Schenone, A.V.; Alfano, O.M. Photo-Fenton degradation of the herbicide 2,4-in aqueous medium at pH conditions close to neutrality. J. Environ. Manag. 2016, 170, 60-69. [CrossRef]

32. Hu, L.; Wang, P.; Xiong, S.; Chen, S.; Yin, X.; Wang, L.; Wang, H. The attractive efficiency contributed by the in-situ reactivation of ferrous oxalate in heterogeneous Fenton process. Appl. Surf. Sci. 2019, 467-468, 185-192. [CrossRef]

33. Chauhan, R.; Dinesh, G.K.; Alawa, B.; Chakma, S. A critical analysis of sono-hybrid advanced oxidation process of ferrioxalate system for degradation of recalcitrant pollutants. Chemosphere 2021, 277, 130324. [CrossRef]

34. Gu, H.; Hargreaves, J.S.J.; Jiang, J.Q.; Rico, J.L. Potential Routes to Obtain Value-Added Iron-Containing Compounds from Red Mud. J. Sustain. Metall. 2017, 3, 561-569. [CrossRef]

35. Kobayashi, H.; Ikeda, T.; Mitamura, T.; Kakizaki, K.; Hiratsuka, N. Preparation of magnetic particles by the pyrolysis of ferrous oxalate in various atmospheres. Funtai Oyobi Fummatsu Yakin/J. Japan Soc. Powder Powder Metall. 1996, 43, 89-94. [CrossRef]

36. Jia, Y.; Ni, J.; Fang, F. Thermal decomposition of ferrous oxalate nanowires to porous nanowire-like $\alpha-\mathrm{Fe}_{2} \mathrm{O}_{3}$ with a good gas-sensing properties. Mater. Sci. Semicond. Process. 2021, 125, 105650. [CrossRef]

37. Lagos, K.J.; Marinkovic, B.A.; Dosen, A.; Guamán, M.V.; Guerrero, V.H.; Pardo, E.; Pontón, P.I. Data on phase and chemical compositions of black sands from "El Ostional" beach situated in Mompiche, Ecuador. Data Br. 2020, 32, 106214. [CrossRef] [PubMed]

38. Crossey, L.J. Thermal degradation of aqueous oxalate species. Geochim. Cosmochim. Acta 1991, 55, 1515-1527. [CrossRef]

39. Martinez-Monteagudo, S.I.; Saldaña, M.D. Chemical Reactions in Food Systems at High Hydrostatic Pressure. Food Eng. Rev. 2014, 6, 105-126. [CrossRef]

40. Van Eldik, R.; Asano, T.; Le Noble, W.J. Activation and Reaction Volumes in Solution. 2. Chem. Rev. 1989, 89, 549-688. [CrossRef]

41. Chen, B.; Hoffmann, R.; Cammi, R. The Effect of Pressure on Organic Reactions in Fluids-A New Theoretical Perspective. Angew. Chemie-Int. Ed. 2017, 56, 11126-11142. [CrossRef]

42. Demazeau, G. High Pressure and Chemical Bonding in Materials Chemistry. ChemInform 2006, 61b, 799-807. [CrossRef]

43. Brown, N.E.; Navrotsky, A.; Nord, G.L.; Banerjee, S.K. Hematite-ilmenite $\left(\mathrm{Fe}_{2} \mathrm{O}_{3}-\mathrm{FeTiO}_{3}\right)$ solid solutions: Determinations of Fe-Ti order from magnetic properties. Am. Mineral. 1993, 78, 941-951.

44. Cao, G.; Yi, N. Quantitative Analysis of Anatase-Rutile Mixtures by Raman Spectroscopy. ChemistrySelect 2020, 5, 11530-11533. [CrossRef]

45. Frost, R.L. Raman spectroscopy of natural oxalates. Anal. Chim. Acta 2004, 517, 207-214. [CrossRef]

46. Molnár, Á. Acids and Acid Catalysis-Homogeneous. In Encyclopedia of Catalysis; John Wiley \& Sons, Inc.: Hoboken, NJ, USA, 2011.

47. Jung, Y.H.; Kim, K.H. Acidic Pretreatment. In Pretreatment of Biomass: Processes and Technologies; Ashok, P., Sangeeta, N., Paramenswaran, B., Christian, L., Eds.; Elsevier Inc.: Amsterdam, The Netherlands, 2015; pp. 27-50. [CrossRef]

48. Plaza, M.; Turner, C. Pressurized hot water extraction of bioactives. TrAC Trends Anal. Chem. 2015, 71, 39-54. [CrossRef]

49. Möller, M.; Nilges, P.; Harnisch, F.; Schröder, U. Subcritical Water as Reaction Environment: Fundamentals of Hydrothermal Biomass Transformation. Chem. Sus. Chem. 2011, 4, 566-579. [CrossRef] [PubMed]

50. Perry, S.C.; Gateman, S.M.; Stephens, L.I.; Lacasse, R.; Schulz, R.; Mauzeroll, J. Pourbaix Diagrams as a Simple Route to First Principles Corrosion Simulation. J. Electrochem. Soc. 2019, 166, C3186-C3192. [CrossRef]

51. Arnaut, L. Elementary reactions in solution. In Chem. Kinet, 2nd ed.; Arnaut, L., Ed.; Elsevier Inc.: Amsterdam, The Netherlands, 2021; pp. 263-293. [CrossRef] 
52. Lee, S.O.; Tran, T.; Park, Y.Y.; Kim, S.J.; Kim, M.J. Study on the kinetics of iron oxide leaching by oxalic acid. Int. J. Miner. Process. 2006, 80, 144-152. [CrossRef]

53. Vehmaanperä, P.; Gong, B.; Sit, P.H.L.; Salmimies, R.; Barbiellini, B.; Häkkinen, A. Formation of Humboldtine during the dissolution of hematite in oxalic acid-Density Funtional Theory (DFT) calculations and experimetal verification. Clays Clay Miner. 2021, 69, 1-8. [CrossRef]

54. Lee, S.O.; Tran, T.; Jung, B.H.; Kim, S.J.; Kim, M.J. Dissolution of iron oxide using oxalic acid. Hydrometallurgy 2007, 87, 91-99. [CrossRef]

55. Shahien, M.G.; Khedr, M.M.H.; Maurice, A.E.; Farghali, A.A.; Ali, R.A.M. Synthesis of high purity rutile nanoparticles from medium-grade Egyptian natural ilmenite. Beni-Suef Univ. J. Basic Appl. Sci. 2015, 4, 207-213. [CrossRef]

56. Salmani Nuri, O.; Irannajad, M.; Mehdilo, A. Effect of surface dissolution by oxalic acid on flotation behavior of minerals. J. Mater. Res. Technol. 2019, 8, 2336-2349. [CrossRef]

57. Omidi, M.H.; Nuri, O.S.; Tavakoli, H.; Omidi, M.H.; Nuri, O.S.; Tavakoli, H. Optimization of Ilmenite Dissolution by Synergistic Effect of Oxalic Acid and Hydrochloric Acid for Preparing Synthetic Rutile. Int. J. Nonferrous Metall. 2018, 7, 25-38. [CrossRef]

58. Corbin, D.R.; Griffin, T.P.; Keith, P.; Hutchenson, K.; Sheng, L.; Shiflett, M.B.; Toradi, C.; Zaher, J.J. Processes for Producing Titanium Dioxide. AU2006352486B2, 28 December 2006.

59. Truong, Q.D.; Le, T.H.; Liu, J.Y.; Chung, C.C.; Ling, Y.C. Synthesis of $\mathrm{TiO}_{2}$ nanoparticles using novel titanium oxalate complex towards visible light-driven photocatalytic reduction of $\mathrm{CO}_{2}$ to $\mathrm{CH}_{3} \mathrm{OH}$. Appl. Catal. A Gen. 2012, 437-438, 28-35. [CrossRef]

60. Anastas, P.; Eghbali, N. Green Chemistry: Principles and Practice. Chem. Soc. Rev. 2009, 39, 301-312. [CrossRef]

61. García-Fernández, A.J.; Espín, S.; Gómez-Ramírez, P.; Martínez-López, E. Oxalates. In Encyclopedia of Toxicology, 3rd ed.; Wexler, P., Ed.; Elsevier Inc.: Amsterdam, The Netherlands, 2014; Volume 1, pp. 730-734. [CrossRef]

62. Swaney, R.; Akhtar, M.; Horn, E.; Lentz, M.; Klungness, J.; Sabourin, M. Oxalic acid pretreatment for mechanical pulping greatly improves paper strength while maintaining scattering power and reducing shives and triglycerides. In 2003 TAPPI Fall Technical Conference: Engineering, Pulping \& PCEEI; TAPPI Press: Atlanta, GA, USA, 2003.

63. Ado, A.; Yahaya, H.; Kwalli, A.A.; Abdulkadir, R. Dyeing of Textiles with Eco-Friendly Natural Dyes: A Review. Int. J. Environ. Monit. Prot. 2015, 1, 76-81.

64. Veeken, A.H.M.; Hamelers, H.V.M. Removal of heavy metals from sewage sludge by extraction with organic acids. Water Sci. Technol. 1999, 40, 129-136. [CrossRef]

65. Oustan, S.; Heidari, S.; Neyshabouri, M.R.; Reyhanitabar, A.; Bybordi, A. Removal of heavy metals from a contaminated calcareous soil using oxalic and acetic acids as chelating agents. In Proceedings of the International Conference on Environment Science and Engineering, Bali Island, Indonesia, 1-3 April 2011.

66. Gaber, S.E.; Rizk, M.S.; Yehia, M.M. Extraction of certain heavy metals from sewage sludge using different types of acids. Biokemistri 2011, 23, 41-48.

67. Kim, J.O.; Lee, Y.W.; Chung, J. The role of organic acids in the mobilization of heavy metals from soil. KSCE J. Civ. Eng. 2013, 17, 1596-1602. [CrossRef]

68. Wei, M.; Chen, J.; Wang, X. Removal of arsenic and cadmium with sequential soil washing techniques using Na2EDTA, oxalic and phosphoric acid: Optimization conditions, removal effectiveness and ecological risks. Chemosphere 2016, 156, 252-261. [CrossRef]

69. Palmieri, F.; Estoppey, A.; House, G.L.; Lohberger, A.; Bindschedler, S.; Chain, P.S.G.; Junier, P. Oxalic acid, a molecule at the crossroads of bacterial-fungal interactions. Adv. Appl. Microbiol. 2019, 106, 49-77. [CrossRef] 